\title{
Aspek Hukum Atas Tuntutan Tenaga Kerja Terhadap Perusahaan Menurut UU No 13 Tahun 2003 Tentang Ketenaga Kerjaan
}

\author{
S. Sokhib \\ Fakultas Hukum, Universitas Muhammadiyah Sorong \\ Email : Sokhib.naim@gmail.com
}

\begin{abstract}
Abstrak
Undang-undang Nomor 13 tahun 2003 tentang ketenagakerjaan telah melakukan pembaharuan terhadap beberapa peraturan perundang-undangan perburuhan baik peninggalan colonial belanda maupun peraturan perundang-undangan nasional yang sudah dirasakan tidak sesuai lagi dengan kebutuhan saat ini. Dalam Pasal 1 angka 1 undang-undang Nomor 13 tahun 2003 menyebutkan bahwa; Ketenagakerjaan adalah segala hal yang berhubungan dengan tenaga kerja pada waktu sebelum, selama dan sesudah masa kerja. Dalam praktek dilapangan Tenaga kerja/ karyawan berperan meningkatkan produktifitas nasional dan kesejahteraan. Untuk itu tenaga kerja harus diberdayakan supaya mereka memiliki nilai lebih dalam arti lebih mampu, lebih terampil dan lebih berkwalitas, agar dapat berdaya guna secara optimal dalam pembangunan nasional dan mampu bersaing dalam era globalisasi. Kemampuan keterampilan dan keahlian tenaga kerja perlu terus menerus ditingkatkan melalui perencanaan dan program ketenagakerjaan termasuk pelatihan pemagangan dan pelayanan penempatan tenaga kerja.
\end{abstract}

Kata Kunci : Hukum Perjanjian Kerja, Hukum Perburuhan, Hukum Ketenagakerjaan

\section{PENDAHULUAN}

Salah satu persoalan yang paling menyolok adalah ketika terjadi Pemutusan Hubungan Kerja yang dilakukan oleh perusahaan pada tahun 2014 tepatnya pada bulan Maret, dimana 15 karyawan telah di lakukan pemutusan hubungan kerjanya akibat dari pelanggaran indisipliner yang dilakukan oleh para karyawan tersebut. Salah satu penyebabnya adalah adanya perbedaan persepsi antara pihak pengusaha dan pihak karyawan terkait dengan Prosedur Pemutusan Hubungan Kerja (PHK) yang dilakukan oleh perusahaan, dimana pihak perusahaan berpedoman kepada Peraturan Perusahaan yang termuat dalam pasal 36 ayat 5 yang berbunyi ; "Pemberian sanksi oleh perusahaan tidak harus mengikuti urutan/ jenis pelanggaran seperti tersebut diatas, akan tetapi tergantung pada berat ringannya pelanggaran".

Dimana peraturan perusahaan adalah merupakan pedoman perusahaan dan karyawan dalam menjalankan tugas dan fungsinya masing-masing, peraturan perusahaan adalah produk hukum yang sah yang dibuat oleh instansi yang berwenang berdasarkan ketentuan pasal 108 undang-undang nomor 13 tahun 2003 tentang ketenagakerjaan yang berbunyi ; (1) Pengusaha yang mempekerjakan pekerja/ buruh sekurang-kurangnya 10 (sepuluh) orang wajib membuat peraturan perusahaan yang mulai berlaku setelah disahkan oleh menteri atau pejabat yang ditunjuk; (2) 
Kewajiban membuat peraturan perusahaan sebagaimana dimaksud dalam ayat (1) tidak berlaku bagi perusahaan yang telah memiliki perjanjian kerja bersama.

Dalam praktek dilapangan Tenaga kerja/ karyawan berperan meningkatkan produktifitas nasional dan kesejahteraan. Untuk itu tenaga kerja harus diberdayakan supaya mereka memiliki nilai lebih dalam arti lebih mampu, lebih terampil dan lebih berkwalitas, agar dapat berdaya guna secara optimal dalam pembangunan nasional dan mampu bersaing dalam era globalisasi. Kemampuan keterampilan dan keahlian tenaga kerja perlu terus menerus ditingkatkan melalui perencanaan dan program ketenagakerjaan termasuk pelatihan pemagangan dan pelayanan penempatan tenaga kerja.

"Sebagai salah satu aspek dari pembangunan, tenaga kerja perlu memperoleh perlindungan dalam semua aspek, termasuk perlindungan untuk memperoleh pekerjaan di dalam dan di luar negeri, perlindungan hak-hak dasar pekerja, perlindungan atas keselamatan dan kesehatan kerja serta perlindungan upah dan jaminan social sehinggan menjamin rasa aman, tentram, terpenuhinya keadilan serta wujudnya kehidupan yang sejahtera lahir dan batin, selaras, serasi dan seimbang”.

Pengertian ini sesuai dengan perkembangan ketenagakerjaan saat ini yang sudah sedemikian pesat akibat intervensi pemerintah. Karena itulah subtansi kajian hukum ketenagakerjaan tidak hanya meliputi hubungan antara buruh dan pekerja dalam hubungan kerja semata, tetapi telah bergeser menjadi hubungan hukum antara pekerja, pengusaha dan pemerintah yang subtansi kajian tidak hanya mengatur hubungan hukum dalam hubngan kerja saja (during employ-ment), tetapi "mulai dari sebelum hubungan kerja (pra employ-ment) sampai setelah hubungan kerja (pasca employment) konsep ketenagakerjaan inilah yang dijadikan acuan untuk mengkaji perangkat hukum yang ada sekarang, apakah sudah meliputi bidang-bidang tersebut atau belum".

Pasal 88 undang-undang Nomor 13 tahun 2003 tentang Ketenagakerjaan menyatakan bahwa; (1) Setiap pekerja/buruh berhak memperoleh penghasilan yang memenuhi penghidupan yang layak bagi kemanusiaan; (2) Untuk mewujudkan penghasilan yang memenuhi penghidupan yang layak bagi kemanusiaan sebagaimana dimaksud adalam ayat 1, pemerintah menetapkan kebijakan pengupahan yang melindungi pekerja/buruh; (3) Kebijakan pengupahan yang melindungi pekerja/buruh sebagimana dimaksud dalam ayat 2 meliputi; (a) Upah minimum; (b) Upah kerja lembur; (c) Upah tidak masuk kerja karena berhalangan; (d) Upah tidak masuk kerja karena melakukan kegiatan lain diluar pekerjaannya; (e) Upah karena menjalankan hak waktu 
istirahat kerjanya; (f) Bentuk dan cara pembayaran upah; (g) Denda dan potongan upah; (h) Halhal yang dapat diperhitungkan dengan upah; (i) Struktur dan skala pengupahan yang proporsional; (j) Upah untuk pembayaran pesangon ; dan (k) Upah untuk perhitungan pajak penghasilan.; (4) Pemerintah menetapkan upah minimum sebagaimana dimaksud dalam ayat 3 huruf a berdasarkan kebutuhan hidup layak dan dengan memperhatikan produktifitas dan pertumbuhan ekonomi.

Di dalam hubungan kerja, kewajiban yang utama dan terpenting bagi pengusaha/majikan sebagai akibat langsung pelaksanaan perjanjian kerja adalah membayar upah tepat pada waktunya. Ketentuan ini jelas ditegaskan pada Pasal 1602 KUHperdata yang berbunyi ;"Majikan wajib membayar upah kepada buruh pada waktu yang ditentukan".

Untuk mengetahui apa yang dimaksud dengan upah dapat dilihat pada undang-undang Nomor 13 tahun 2003 tentang Ketenagakerjaan dalam Pasal 1 angka 30 menyatakan ; Upah adalah hak pekerja/buruh yang diterima dan dinyatakan dalam bentuk uang sebagai imbalan dari pengusaha atau pemberi kerja kepada pekerja/buruh yang ditetapkan dan dibayarkan menurut suatu perjanjian kerja, kesepakatan, atau peraturan perundang-undangan, termasuk tunjangan bagi pekerja/buruh dan keluarganya atas suatu pekerjaan dan/ atau jasa yang telah atau akan dilakukan.

Sedangkan menurut pasal 1 huruf a Peraturan Pemerintah Nomor 8 tahun 1981 yang dimaksud dengan upah adalah ; Suatu penerimaan sebagai imbalan dari pengusaha kepada buruh untuk sesuatu pekerjaan atau jasa yang telah atau akan dilakukan, dinyatakan atau dinilai dalam bentuk uang yang ditetapkan menurut suatu persetujuan atau perundang-undangan, dan dibayar atas dasar suatu perjanjian kerja antara pengusaha dengan buruh, termasuk tunjangan baik untuk buruh sendiri maupun keluarganya.

Menurut Surat Edaran Menteri Tenaga Kerja RI, Nomor ; SE-07/MEN/1990 tentang pengelompokan komponen upah dan pendapatan non upah disebutkan sebagai berikut ;(1) Termasuk komponen upah adalah ; (a) Upah pokok ; imbalan dasar yang dibayarkan kepada buruh menurut tingkat atau jenis pekerjaan yang besarnya ditetapkan berdasarkan perjanjian; (b) Tunjangan tetap ; suatau pembayaran yang teratur berkaitan dengan pekerjaan yang diberikan secara tetap untuk buruh dan keluarganya yang dibayarkan bersamaan dengan upah pokok seperti tunjangan anak, tunjangan kesehatan, tunjangan kemahalan, tunjangan daerah dan lain sebagainya; (c) Tunjangan makan, tunjangan transport dapat dimasukkan dalam tunjangan pokok asal tidak dikaitkan dengan kehadiran buruh, maksudnya tunjangan tersebut diberikan tanpa mengindahkan hadir atau tidaknya buruh dan diberikan bersamaan dibayarnya upah pokok; (d) Tunjangan tidak 
tetap ; suatu pembayaran yang secara langsung atau tidak langsung berkaitan dengan buruh dan diberikan secara tidak tetap bagi buruh dan keluarganya serta dibayarkan tidak bersamaan dengan upah pokok seperti tunjangan transport diberikan berdasarkan kehadirannya; (2) Bukan termasuk komponen upah adalah; (a) Fasilitas ; kenikamtan dalam bentuk nyata/natural karena hal-hal yang bersifat khusus atau untuk meningkatkan kesejahteraan buruh, seperti fasilitas kendaraan antar jemput, pemberian makan secara cuma-cuma, sarana ibadah, tempat penitipan bayi, koperasi, kantin dan sebagainaya; (b) Bonus ; pembayaran yang diterima buruh dari hasil keuntungan perusahaan atau karena buruh berprestasi melebihi target produksi yang normal atau karena peningkatan produktifitas; (c) Tunjangan hari raya (THR), gratifikasi dan pembagian keuntungan lain.

Tidak ada upah apabila buruh tidak melakukan pekerjaan. Hal ini ditegaskan oleh pasal 1602b KUHPerdata dan pasal 4 Peraturan Pemerintah Nomor 8 tahun 1981 tentang Perlindungan Upah. Ketentuan tersebut juga tercermin dalam pasal 93 Undang-undang Nomor 13 tahun 2003 ayat 1 yang berbunyi ;

"upah tidak dibayar apabila pekerja/bruh tidak melakukan pekerjaan"

Yang demikian ini logis, sebab pada dasarnya upah merupakan imbalan pekerjaan yang telah dilakukan oleh buruh. Meskipun demikian undang-undang meletakkan kewajiban kepada majikan untuk membayar upah dalam hal buruh tidak melakukan pekerjaan perkecualian yang ditentukan oleh undang-undang tersebut dalam ayat 2 sebagai berikut; (a) Pekerja/buruh sakit sehingga tidak dapat melakukan pekerjaan; (b) Pekerja atau buruh perempuan yang sakit pada hari pertama dan kedua masa haidnya sehingga tidak dapat melakukan pekerjaan; (c) Pekerja /atau buruh tidak masuk bekerja karena pekerja/buruh menikah, menikahkan,mengkhitankan, membabtiskan anaknya, istri melahirkanatau keguguran kandungan, suami atau istri atau anak atau menantu atau orang tua atau mertua atau anggota keluarga dalam satu rumah tangga meninggal dunia; (d) Pekerja/buruh tidak dapat melakukan pekerjaannya karena sedang menjalankan kewajiban terhadap Negara; (e) Pekerja/buruh tidak dapat melakukan pekerjaannya karena menjalankan ibadah yang diperintahkan agamanya; (f) Pekerja/buruh bersedia melakukan pekerjaan yang telah dijanjikan tetapi pengusaha tidak mempekerjakannya, baik karena kesalahan sendiri maupun halangan yang seharusnya dapat dihindari pengusaha; (g) Pekerja/buruh melaksanakan hak istirahat; (h) Pekerja/buruh melaksanakan tugas serikat pekerja/serikat buruh atas persetujuan pengusaha ; dan (i) Pekerja/buruh melaksanakan tugas pendidikan dari perusahaan ; 
Mengenai hal ini juga diatur dalam pasal 1602 c KUHPerdata yang menegaskan sebagai berikut ; "akan tetapi buruh berhak atas upah yang ditetapkan menurut jangka waktu untuk waktu yang agak pendek apabila ia karena sakit atau kecelakaan berhalangan melakukan pekerjaan kecuali bila sakinya atau kecelakaannya itu disebabkan karena kesengajaan atau tindak susilanya atau akibat cacat badan yang pada waktu membuat oerjanjian ia berikan dengan keterangan palsu kepada majikan".

Dengan demikian menurut pasal 1602 c KUHPerdata tersebut, meskipun sakit atau kecelakaan berhalangan melakukan pekerjaan, tetap saja ia tidak mendapatkan upah, apabila sakitnya atau kecelakaan berhalangan melakukan pekerjaannya itu disebabkan oleh (a) kesengajaan, (b) perbuatan tindak susila, dan (c) akibat cacat badan yang pada waktu membuat perjanjian ia berikan dengan sengaja berupa keterangan palsu. Perjanjian kerja dibuat pada dasarnya juga menetapkan ketentuan yang sama dengan ketentuan dinas, hal itu ditegaskan dalam pasal 416 KUHDagang yang berbunyi ; “ apabila seorang buruh yang telah membuat suatu perjanjian kerja untuk paling sedikit satu tahun, atau selama satu setengah tahun terus-menerus telah melakukan pekerjaan bagi pengusaha, ditimpa oleh sakit atau suatu kecelakaan pada waktu sedang bekerja di kapal, maka apabila hubungan kerja itu berakhir lebih dahulu berhaklah dia sepenuhnya atas bagian upahnya yang harus dibayar dalam uang dan hendaklah ia pula sepenuhnya atas perawatan dan pengobatan selam berada di kapal “.

Majikan wajib membayar upah kepada buruh pada saat terjadinya perjanjian kerja sampai perjanjian kerja berakhir. Pengusaha dalam menetapkan upah tidak boleh mengadakan diskriminasi antara buruh laki-laki dan buruh wanita untuk pekerjaan yang sama nilainya.

Ketentuan tersebut diatas merupakan pelaksanaan dari Konvensi Organisasi Perburuhan International No. 100 tahun 1951 mengenai pengupahan bagi buruh laki-laki dan wanita untuk pekerjaan yang sama nilainya dan telah di ratifikasi oleh Pemerintah Indonesia dengan Undangundang Nomor 80 tahun 1957.

Adapun isi pokok dari konvensi Nomor 100 tahun 1951 adalah sebagai berikut; (1) Yang dimaksud istilah pengupahan meliputi upah atau gaji biasa, pokok atau minimum dan pendapatan tambahan apapun juga yang harus dibayar secara tunai atau dengan barang oleh majikan kepada buruh berhubung dengan pekerjaan buruh; (2) Istilah pengupahan yang sama bagi buruh laki-laki dan wanita untuk pekerjaan yang sama nilainya dimaksud nilai pengupahan yang diadakan tanpa diskriminasi berdasarkan jenis kelamin; (3) Pemerintah harus menjamin pelaksanaan pengupahan 
yang sama antara buruh laki-laki dan wanita untuk pekerjaan yang sama nilainya; (4) Pemerintah harus menjamin pelaksanaan pengupahan yang sama antara buruh laki-laki dan wanita dengan jalan; (5) Dimuat dalam Peraturan Perundang-undangan Nasional (lihat PP No.8/1981); (6) Mendirikan badan penetapan upah; (7) Membuat perjanjian perburuhan atau dengan cara lain.

Pada setiap pembayaran upah, seluruh jumlah upah harus dibayarkan. Menurut pasal 10 ayat 1 PP Nomor 8 tahun 1981 menyebutkan ; "upah harus dibayarkan langsung kepada buruh pada waktu yang telah ditentukan sesuai dengan perjanjian”. Ketentuan tersebut diatas dimaksudkan agar pembayaran upah tidak jatuh kepada orang yang tidak berhak dengan kata lain upah harus dibayarkan kepada buruh itu sendiri. Ketentuan ini merupakan asas hukum dimana pembayaran harus dilakukan kepada si berpiutang atau kepada orang lain yang dikuasakan oleh si berpiutang tersebut (Pasal 1385 KUHPerdata).; (1) Apakah prosedur PHK yang dilakukan oleh perusahaan terhadap karyawan sudah sesuai dengan Peraturan Perundang-undangan?; (2) Bagaimana konsekwensi hak normatif yang seharusnya diberikan oleh perusahaan kepada mantan karyawan yang sudah di PHK berdasarkan ketentuan undang-undang nomor 13 tahun 2003 tentang ketenagakerjaan?

\section{PEMBAHASAN}

\section{Dasar Hukum Pemutusan Hubungan Kerja (PHK)}

Dalam dunia kerja, kita lazim mendengar istilah Pemutusan Hubungan Kerja atau yang sering disingkat dengan kata PHK. PHK sering kali menimbulkan keresahan khususnya bagi para pekerja. Bagaimana tidak, Keputusan PHK ini akan berdampak buruk bagi kelangsungan hidup dan masa depan para pekerja serta keluarga yang mengalaminya. Bagaimana aturan Pemutusan Hubungan Kerja menurut Undang-Undang Ketenagakerjaan?

Menurut pasal 61 Undang - Undang No. 13 tahun 2003 tentang ketenagakerjaan, perjanjian kerja dapat berakhir apabila; (a) Pekerja meninggal dunia; (b) Jangka waktu kontrak kerja telah berakhir; (c) Adanya putusan pengadilan atau penetapan lembaga pphi (penyelesaian perselisihan hubungan industrial) yang telah mempunyai kekuatan hukum tetap; (d) Adanya keadaan atau kejadian tertentu yang dicantumkan dalam perjanjian kerja, peraturan perusahaan, atau pkb (perjanjian kerja bersama) yang dapat menyebabkan berakhirnya hubungan kerja. 
Jadi, pihak yang mengakhiri perjanjian kerja sebelum jangka waktu yang ditentukan, wajib membayar ganti rugi kepada pihak lainnya sebesar upah pekerja/buruh sampai batas waktu berakhirnya jangka waktu perjanjian kerja.

Perusahaan dapat melakukan PHK (Pemutusan Hubungan Kerja) apabila pekerja melakukan pelanggaran terhadap perjanjian kerja, peraturan perusahaan atau perjanjian kerja bersama (PKB). Akan tetapi sebelum mem-PHK, perusahaan wajib memberikan surat peringatan secara 3 kali berturut-turut. Perusahaan juga dapat menentukan sanksi yang layak tergantung jenis pelanggaran, dan untuk pelanggaran tertentu, perusahaan bisa mengeluarkan SP (Surat Peringatan) Ke-3 (tiga) secara langsung atau langsung memecat. Semua hal ini diatur dalam perjanjian kerja, peraturan perusahan masing-masing. Karena setiap perusahaan mempunyai peraturan yang berbeda-beda.

Selain karena kesalahan pekerja, pemecatan mungkin dilakukan karena alasan lain. Misalnya bila perusahaan memutuskan melakukan efisiensi, penggabungan atau peleburan, dalam keadaan merugi/pailit. PHK akan terjadi karena keadaan diluar kuasa perusahaan.

Bagi pekerja yang di PHK, alasan PHK berperan besar dalam menentukan apakah pekerja tersebut berhak atau tidak berhak atas uang pesangon, uang penghargaan dan uang penggantian hak. Peraturan mengenai uang pesangon, uang penghargaan dan uang penggantian hak diatur dalam Pasal 156, pasal 160 sampai Pasal 169 UU No. 13 tahun 2003 tentang Ketenagakerjaan. Menurut UU No. 13 Tahun 2003 Tentang Ketenagakerjaan, pihak perusahaan dapat saja melakukan PHK dalam berbagai kondisi seperti di bawah ini:

\section{Pengunduran Diri Secara Baik-Baik Atas Kemauan Sendiri}

Bagi pekerja yang mengundurkan diri secara baik-baik tidak berhak mendapat uang pesangon sesuai ketentuan Pasal 156 ayat 2, UU No. 13 Tahun 2003 Tentang Ketenagakerjaan. Yang bersangkutan juga tidak berhak mendapatkan uang penghargaan masa kerja sesuai ketentuan Pasal 156 ayat 3, UU No. 13 Tahun 2003 Tentang Ketenagakerjaan tetapi berhak mendapatkan uang penggantian hak mendapatkan 1 kali ketentuan Pasal 156 ayat 4, UU No. 13 Tahun 2003 Tentang Ketenagakerjaan.

Apabila pekerja tersebut mengundurkan diri secara mendadak tanpa mengikuti prosedur sesuai ketentuan yang berlaku (diajukan 30 hari sebelum tanggal pengunduran diri) maka pekerja tersebut hanya mendapatkan uang penggantian hak. Tetapi kalau mengikuti prosedur maka pekerja 
tersebut mendapatkan uang pisah yang besar nilainya berdasarkan kesepakatan antara pengusaha dan pekerja yang tertuang dalam Perjanjian Kerja Bersama (PKB) atau peraturan perusahaan.

\section{Pengunduran Diri Secara Tertulis Atas Kemauan Sendiri Karena Berakhirnya Hubungan Kerja}

Bagi pekerja kontrak yang mengundurkan diri karena masa kontrak berakhir, maka pekerja tersebut tidak mendapatkan uang pesangon sesuai ketentuan Pasal 154 ayat 2 dan uang penghargaan masa kerja sesuai ketentuan Pasal 156 ayat 3 juga uang pisah tetapi berhak atas penggantian hak sesuai ketentuan Pasal 156 ayat 4 .

\section{Pengunduran Diri Karena Mencapai Usia Pensiun.}

Mengenai batasan usia pensiun perlu disepakati antara pengusaha dan pekerja dan dituangkan dalam perjanjian kerja bersama atau peraturan perusahaan. Batasan usia pensiun yang dimaksud adalah penentuan usia berdasarkan usia kelahiran dan berdasarkan jumlah tahun masa kerja.

Contoh : Seseorang pekerja dikatakan pensiun apabila sudah mencapai usia 55. Apabila seorang pekerja sudah mencapai usia 55 tahun maka secara otomatis dikategorikan pensiun walaupun masa kerjanya belum mencapai 25 tahun. Tetapi sebaliknya walaupun usianya belum mencapai 55 tahun tetapi lama masa kerja sudah mencapai 25 tahun berturut-turut di perusahaan yang sama maka pekerja tersebut dikategorikan pensiun. Apa pun kategori pensiunnya, pekerja tersebut berhak mendapat uang pesangon 2 kali ketentuan Pasal 156 ayat 2 dan uang penghargaan masa kerja 1 kali ketentuan Pasal 156 ayat 4, UU No. 13 Tahun 2003 Tentang Ketenagakerjaan tetapi tidak berhak mendapat uang pisah.

\section{Pekerja Melakukan Kesalahan Berat}

Kesalahan apa saja yang termasuk dalam kategori kesalahan berat...?; (a) Pekerja telah melakukan penipuan, pencurian, penggelapan barang dan atau uang milik perusahan; (b) Pekerja memberikan keterangan palsu atau yang dipalsukan sehingga merugikan perusahan; (c) Pekerja mabuk, minum - minuman keras, memakai atau mengedarkan narkotika, psikotropika, dan zat aktif lainnya, dilingkungan kerja; (d) Melakukan perbuatan asusila atau perjudian di lingkungan kerja; (e) Menyerang, menganiaya, mengancam, atau mengintimidasi, teman sekerja atau perusahaan dilingkungan kerja; (f) Membujuk teman sekerja atau perusahaan untuk melakukan perbuatan yang bertentangan dengan Undang-undang; (g) Dengan ceroboh atau sengaja merusak atau membiarkan dalam keadaan bahaya barang milik perusahaan yang menimbulkan kerugian bagi perusahaan; (h) Dengan ceroboh atau sengaja membiarkan teman sekerja atau perusahaan dalam keadaan bahaya 
ditempat kerja; (i) Membongkar atau membocorkan rahasia perusahaan yang seharusnya dirahasiakan kecuali untuk kepentingan Negara; (j) Melakukan perbuatan lainnya dilingkungan perusahaan yang diancam hukuman pidana penjara 5 (lima) tahun atau lebih.

Pekerja yang diputuskan hubungan kerjanya berdasarkan kesalahan berat hanya dapat memperoleh uang pengganti hak sedang bagi pekerja yang tugas dan fungsi tidak mewakili kepentingan perusahaan secara langsung,selain memperoleh uang pengganti, juga diberikan uang pisah yang besarnya diatur dalam Perjanjian Kerja, Peraturan Perusahaan, dan atau Perjanjian Kerja Bersama (PKB).

\section{Pekerja Ditahan Pihak Yang Berwajib.}

Perusahaan dapat melakukan Pemutusan Hubungan Kerja terhadap pekerja setelah 6 (enam) bulan tidak melakukan pekerjaan yang disebabkan masih dalam proses pidana. Dalam ketentuan bahwa perusahaan wajib membayar kepada pekerja atau buruh uang penghargaan masa kerja sebesar 1 (satu) kali ditambah uang pengganti hak.

Untuk Pemutusan Hubungan Kerja ini tanpa harus ada penetapan dari lembaga Penyelesaian Hubungan Industrial tetapi apabila Pengadilan memutuskan perkara pidana sebelum 6 (enam) bulan dan pekerja dinyatakan tidak bersalah, perusahaan wajib mempekerjakan kembali.

\section{Perusahaan/Perusahaan Mengalami Kerugian}

Apabila perusahaan bangkrut dan ditutup karena mengalami kerugian secara terus menerus selama 2 (dua) tahun, perusahaan dapat melakukan Pemutusan Hubungan Kerja terhadap pekerja. Syaratnya adalah harus membuktikan kerugian tersebut dengan laporan keuangan 2 (dua) tahun terakhir yang telah diaudit oleh akuntan publik. Dan perusahaan wajib memberikan uang pesangon 1 (satu) kali ketentuan dan uang pengganti hak

\section{Pekerja Mangkir Terus Menerus}

Perusahaan dapat memutuskan hubungan kerja apabila pekerja tidak masuk selama 5 hari berturut-turut tanpa keterangan tertulis yang dilengkapi bukti-bukti yang sah meskipun telah dipanggil 2 kali secara patut dan tertulis oleh perusahaan. Dalam situasi seperti ini, pekerja dianggap telah mengundurkandiri. Keterangan dan bukti yang sah yang menunjukkan alasan pekerja tidak masuk, harus diserahkan paling lambat pada hari pertama pekerja masuk kerja dan untuk panggilan patut diartikan bahwa panggilan dengan tenggang waktu paling lama 3 hari kerja dengan di alamatkan pada alamat pekerja yang bersangkutan atau alamat yang dicatatkan pada perusahaan. 
Pekerja yang di-PHK akibat mangkir, berhak menerima uang pengganti hak dan uang pisah yang besarnya dalam pelaksanaannya diatur dalam Perjanjian kerja, Peraturan Perusahaan dan Perjanjian Kerja Bersama.

\section{Pekerja Meninggal Dunia}

Hubungan kerja otomatis akan berakhir ketika pekerja meninggal dunia. Perusahaan berkewajiban untuk memberikan uang yang besarnya 2 kali uang pesangon, 1 kali uang penghargaan masa kerja, dan uang pengganti hak. Adapun sebagai ahli waris janda/duda atau kalau tidak ada anak atau juga tidak ada keturunan garis lurus keatas/kebawah selam tidak diatur dalam perjanjian kerja, Peraturan Perusahaan, Perjanjian Kerja Bersama.

\section{Pekerja Melakukan Pelanggaran}

Di dalam hubungan kerja ada suatu ikatan antara pekerja dengan perusahaan yang berupa perjanjian kerja , peraturan perusahaan,dan Perjanjian Kerja Bersama yang dibuat oleh perusahaan atau secara bersama-sama antara pekerja/serikat pekerja dengan perusahaan, yang isinya minimal hak dan kewajiban masing-msing pihak dan syarat-syarat kerja, dengan perjanjian yang telah disetujui oleh masing-masing pihak diharapkan didalam implementasinya tidak dilanggar oleh salah satu pihak.

Pelanggaran terhadap perjanjian yang ada tentunya ada sangsi yang berupa teguran lisan atau surat tertulis, sampai ada juga yang berupa surat peringatan. Sedang untuk surat peringatan tertulis dapat dibuat surat peringatan ke I, ke II, sampai ke III. masing-masing berlakunya surat peringatan selam 6 bulan sehingga apabila pekerja sudah diberi peringatan sampai 3 kali berturutturut dalam 6 bulan terhadap pelanggaran yang sama maka berdasarkan peraturan yang ada kecuali ditentukan lain yang ditetapkan lain dalam perjanjian kerja, peraturan perusahaan, Perjanjian kerja Bersama, maka perusahaan dapat melakukan pemutusan hubungan kerja. Perusahaan Berkewajiban memberikan uang pesangon 1 dari ketentuan, uang penghargaan masa kerja 1 kali ketentuan dan uang pengganti hak yang besarnya ditentukan dalam peraturan yang ada.

\section{Perubahan Status, Penggabungan, Pelemburan Atau Perubahan Kepemilikan}

Bagi pekerja yang diakhiri hubungan kerjanya karena alasan tersebut di atas maka ; (a) Pekerja yang tidak bersedia melanjutkan hubungan kerjanya, pekerja tersebut berhak atas uang pesangon 1 kali sesuai ketentuan pasal 156 ayat 2 dan uang penghargaan masa kerja 1 kali sesuai pasal 156 ayat 3 dan uang penggantian hak sesuai ketentuan pasal 156 ayat 4 dan tidak berhak mendapatkan uang pisah; (b) Perusahaan tidak bersedia menerima pekerja di perusahaannya maka 
bagi pekerja tersebut berhak atas uang pesangon 2 kali ketentuan pasal 156 ayat 2 dan uang penghargaan masa kerja pasal 156 ayat 3 dan uang penggantian hak sesuai ketentuan pasal 156 ayat 4 dan tidak berhak mendapat uang pisah; (c) Pemutusan Hubungan Kerja Karena Alasan Efisiensi.

Bagi pekerja yang mengakhiri hubungan kerjanya karena efisiensi maka pekerja tersebut berhak atas uang pesangon 2 kali ketentuan Pasal 156 ayat 3 dan uang penggantian hak sesuai ketentuan Pasal 156 ayat 3 dan uang penghargaan masa kerja 1 kali ketentuan pasal 156 ayat 4 tetapi tidak berhak mendapatkan uang pisah.

Dalam Pasal 151 ayat (1) UU No. 13 Tahun 2003 Tentang Ketenagakerjaan disebutkan bahwa pengusaha, pekerja/buruh, serikat pekerja/serikat buruh, dan pemerintah, dengan segala upaya harus mengusahakan agar jangan terjadi pemutusan hubungan kerja (PHK). Selanjutnya, Pasal 151 ayat (2) menjelaskan bahwa jika pemutusan hubungan kerja tidak bisa dihindarkan wajib dirundingkan oleh pengusaha dan serikat pekerja/serikat buruh atau dengan pekerja/buruh apabila pekerja/buruh yang bersangkutan tidak menjadi anggota serikat pekerja/serikat buruh.

Ketentuan Pasal 151 ayat (1) dan ayat (2) berarti, PHK tidak boleh dilakukan secara sepihak melainkan harus melalui perundingan terlebih dahulu. Kemudian, apabila hasil perundingan tersebut tidak menghasilkan persetujuan, pengusaha hanya dapat memutuskan hubungan kerja dengan pekerja/buruh setelah memperoleh penetapan dari lembaga penyelesaian perselisihan hubungan industrial. Demikian ketentuan Pasal 151 ayat (3) UU ketenagakerjaan.

Adapun lembaga penyelesaian perselisihan hubungan industrial yang dimaksud adalah mediasi ketenagakerjaan, konsiliasi ketenagakerjaan, arbitrase ketenagakerjaan dan pengadilan hubungan industrial. Hal tersebut diatur lebih jauh di dalam UU No. 2 Tahun 2004 Tentang PPHI (Penyelesaian Perselisihan Hubungan Industrial).

Pemutusan Hubungan Kerja tanpa adanya penetapan dari lembaga penyelesaian hubungan industrial akan menjadi batal demi hukum. Artinya, secara hukum PHK tersebut dianggap belum terjadi (Pasal 155 ayat 1, UU No. 13 Tahun 2003 Tentang Ketenagakerjaan), dan selama putusan lembaga penyelesaian perselisihan hubungan industrial belum ditetapkan, baik pengusaha maupun pekerja/buruh harus tetap melaksanakan segala kewajibannya (Pasal 155 ayat 2, UU No. 13 Tahun 2003 Tentang Ketenagakerjaan). Pekerja/buruh tetap harus bekerja dan Pengusaha tetap harus membayarkan upahnya selama belum ada keputusan dari lembaga penyelesaian perselisihan hubungan industrial. Pengusaha dapat melakukan pengecualian berupa tindakan skorsing kepada 
pekerja/buruh yang sedang dalam proses pemutusan hubungan kerja dengan tetap membayarkan upah beserta hak-hak lainnya yang biasa diterima pekerja/buruh (Pasal 155 ayat 3, UU No. 13 Tahun 2003 Tentang Ketenagakerjaan).

Apa yang harus dilakukan apabila perusahaan tetap tidak mau menerima si karyawan dan tetap tidak mau membayarkan gajinya.... ? Menurut Pasal 96 UU No. 2 Tahun 2004 Tentang PPHI (Penyelesaian Perselisihan Hubungan Industrial), apabila dalam persidangan pertama secara nyata-nyata pihak pengusaha terbukti tidak melaksanakan kewajibannya, maka hakim ketua sidang harus segera memberikan putusan sela berupa perintah kepada pengusaha untuk membayar upah beserta hak-hak lainnya yang biasa diterima pekerja/buruh yang bersangkutan. Jika putusan sela tersebut tidak dilaksanakan oleh pengusaha, Hakim Ketua Sidang memerintahkan Sita Jaminan dalam sebuah Penetapan Pengadilan Hubungan Industrial. Putusan sela tersebut tidak dapat diajukan perlawanan dan/atau tidak dapat digunakan upaya hukum.

Perusahaan dilarang melakukan PHK dengan alas an; (a) Pekerja berhalangan masuk kerja karena sakit menurut keterangan dokter selama waktu tidak melampaui 12 bulan secara terusmenerus; (b) Pekerja berhalangan menjalankan pekerjaannya, karena memenuhi kewajiban terhadap negara sesuai dengan ketentuan peraturan perundang-undangan yang berlaku; (c) Pekerja menjalankan ibadah yang diperintahkan agamanya; (d) Pekerja menikah; (e) Pekerja perempuan hamil, melahirkan, gugur kandungan, atau menyusui bayinya; (f) Pekerja mempunyai pertalian darah dan atau ikatan perkawinan dengan pekerja lainnya di dalam satu perusahaan, kecuali telah diatur dalam perjanjian kerja, peraturan perusahaan, atau perjanjian kerja bersama; (g) Pekerja mendirikan, menjadi anggota dan/atau pengurus serikat pekerja, pekerja melakukan kegiatan serikat pekerja di luar jam kerja, atau di dalam jam kerja atas kesepakatan perusahaan, atau berdasarkan ketentuan yang diatur dalam perjanjian kerja, peraturan perusahaan, atau perjanjian kerja bersama; (h) Pekerja yang mengadukan perusahaan kepada yang berwajib mengenai perbuatan perusahaan yang melakukan tindak pidana kejahatan; (i) Karena perbedaan paham, agama, aliran politik, suku, warna kulit, golongan, jenis kelamin, kondisi fisik, atau status perkawinan; (j) Pekerja dalam keadaan cacat tetap, sakit akibat kecelakaan kerja, atau sakit karena hubungan kerja yang menurut surat keterangan dokter yang jangka waktu penyembuhannya belum dapat dipastikan. 


\section{SIMPULAN.}

Secara konsep, ada dua jenis PHK, yaitu PHK secara sukarela dan PHK dengan tidak sukarela. PHK sukarela, yang diartikan sebagai pengunduran diri buruh tanpa paksaan dan tekanan. Begitu pula karena habisnya masa kontrak, tidak lulus masa percobaan (probation), memasuki usia pensiun dan buruh meninggal dunia. PHK tidak sukarela dapat terjadi karena adanya pelanggaran, baik yang dilakukan buruh maupun pengusaha/perusahaan.

Pemberian surat peringatan tersebut sebagaimana ketentuan pasal 161 diatas Tidak Harus Berjenjang, akan tetapi dapat disesuaikan dengan berat ringannya pelanggaran yang dilakukan, Masing-masing surat peringatan dapat diterbitkan secara berurutan atau tidak, sesuai dengan ketentuan yang diatur dalam Perjanjian Kerja atau Peraturan Perusahaan atau Perjanjian Kerja Bersama.

Pelanggaran terhadap perjanjian yang ada tentunya ada sanksi berupa teguran lisan atau surat tertulis, sampai ada juga yang berupa surat peringatan. Sedang untuk surat peringatan tertulis dapat dibuat surat peringatan ke I, ke II, sampai ke III. masing-masing berlakunya surat peringatan selama 6 bulan, sehingga apabila pekerja sudah diberi peringatan sampai 3 kali berturut-turut dalam 6 bulan terhadap pelanggaran yang sama, maka berdasarkan peraturan yang ada kecuali ditentukan lain yang ditetapkan lain dalam perjanjian kerja, peraturan perusahaan, Perjanjian kerja Bersama, maka perusahaan dapat melakukan pemutusan hubungan kerja. Perusahaan Berkewajiban memberikan uang pesangon 1x dari ketentuan, uang penghargaan masa kerja 1 kali ketentuan dan uang pengganti hak yang besarnya ditentukan dalam peraturan yang ada, sebagaimana ketentuan pasal 156 ayat 2, 3 dan 4 undang-undang nomor 13 tahun 2003 tentang ketenagakerjaan.

\section{DAFTAR PUSTAKA}

Husni, lalu, Hukum Ketenagakerjaan Indonesia, PT. raja grafindo persada Jakarta, 2008, hal.38. Sugiarto Aritonang, Hukum On Line, diakses pada tanggal 29 Juni 2015. Setia tunggal, Hadi, Megenal Hukum Ketenagakerjaan, (Jakarta: Harvarindo, 2014), hlm. 291. Yayasan Lembaga Bantuan Hukum, Panduan Bantuan Hukum di Indonesia, Yayasan Obor Indonesia 2009, hal.262. 